\title{
PRESENCE OF SOMATOMFDIN RECEPTORS ON PRIMARY HUMAN BREAST AND COLON CARCINOMAS
}

MICHAEL N. POLLAK*, JAMES F. PERDUE, RICHARD G. MARGOLESE, KATHY BAER and MARTINE RICHARD

Departments of Medicine and Oncology, McGill University and Lady Davis Research Institute of the Jewish General Hospitah Montreah, Quebec HST 1 E2 (Canada)

\section{SUMMARY}

Competitive binding techniques were used to study the interaction of insulin-like growth factor I (IGF-I) with a plasma membrane-enriched subcellular fraction purified from primary breast and colon carcinoma specimens obtained at surgery. The presence of specific binding sites for IGF-I was detected in all tumour specimens studied. Scatchard analysis and competition studies with insulin and insulin-like growth factor-II (IGF-II) revealed the presence of specific IGF-I receptors, showing a $K_{d}$-value of approximately $2 \mathrm{nM}$. These results are consistent with the hypothesis that somatomedins play a role in determining the proliferative behaviour of human breast and colon tumors, and suggest that recent laboratory studies showing dependence of neoplastic cells on somatomedins for optimum proliferation may have clinical relevance.

\section{INTRODUCTION}

The somatomedins (insulin-like growth factors) are a family of polypeptide mitogens structurally related to proinsulin [1]. IGF-I, a 76 amino acid polypeptide, has been regarded as the key mediator of growth hormone action, and is synthesized by hepatocytes in response to growth hormone stimulation. More recent reports have confirmed that the liver is an important site of growth-hormone induced IGF-I synthesis [2], but have also shown that there are widespread extra-hepatic sites of IGF-I production [3], which may be less directly controlled by growth hormone levels. IGF-II is a 67 amino acid

*Correspondence should be addressed to Dr. Michael Pollak, Lady Davis Research Institute, 3755 Cote St. Catherine Road, Montreal, Quebec H3T 1E2, Canada. 
polypeptide. Its levels are not regulated by growth hormone to the same extent as IGF-I levels are. While IGF-II is generally regarded as an important mitogen involved in the control of fetal cellular proliferation, its role in postnatal life is less clear [4].

The somatomedins have been shown to be potent mitogens for a variety of normal and neoplastic cell types in several in vivo and in vitro experimental systems [1]. As is the case with other peptide growth factors, the mechanism of action of somatomedins is incompletely understood, but a crucial first step involves binding of the mitogen to specific high-affinity cell-surface receptors. IGF-I and IGF-II receptors are distinct from each other and from insulin receptors, each receptor species having highest affinity for its own mitogen. The IGF-I receptor protein has been characterized [5,6], and is thought to have an extracellular IGF-I binding domain, a transmembrane domain, and an intracellular domain that shows limited homology with the intracellular tyrosine-specific protein kinase domain of the epidermal growth factor receptor. It is possible that binding of IGF-I to the extracellular portion of the receptor results in a conformational change that increases the activity of kinase portion, and that this is an important early step in the transduction of the mitogenic signal. Less is known concerning the structure and signal transducing mechanisms of the IGF-II receptor; it has been proposed that despite the higher affinity of IGF-II for its own receptor, its mitogenic effect may at least in some tissues, be mediated through the IGF-I receptor [7].

IGF-I receptors have been detected in a wide variety of normal tissues [8]. It is well known that certain human tumours may retain a degree of dependence on mitogens that normally regulate the proliferation of the tissue of their origin. This dependence has been exploited in clinically useful and widelyapplied hormonal treatments for androgen-dependent prostate cancer and estrogen-dependent breast cancer. We speculated that somatomedins might function as mitogens for human tumours, and therefore surveyed a series of neoplasms for the presence of IGF-I receptors.

\section{MATERIALS AND METHODS}

After careful dissection, fresh surgical specimens obtained at routine operation for primary breast or colon cancer were frozen in liquid nitrogen and stored at $-70^{\circ} \mathrm{C}$. Adjacent tissue was submitted for histological study to confirm diagnosis. After thawing, homogenization was carried out in $50 \mathrm{mM}$ phosphate buffer (pH 7.4) containing 0.25 M sucrose, 2 mM EGT A, 1 mM (PMSF) and Aprotinin, $0.6 \mu \mathrm{g} / \mathrm{ml}$, using a Polytron homogenizer. A plasma-membrane enriched subcellular fraction was prepared by differential centrifugation [9].

${ }^{125}$ I-Labelled recombinant human IGF-I was obtained from Amersham, recombinant IGF-I from Amgen, and insulin from Sigma. Rat IGF-II was purified to homogeneity using previously described methods [10], and amino acid analysis of the purified peptide revealed the composition predicted from IGF-II cDNA [11]. 
Binding assays were performed at $20^{\circ} \mathrm{C}$ for $1 \mathrm{~h}$ using $100 \mu \mathrm{g}$ membrane protein in $250 \mu \mathrm{l}$ of binding buffer $(50 \mathrm{mM}$ phosphate buffer, $1 \mathrm{mg} / \mathrm{ml}$ bovine serum albumin (BSA), and Aprotinin, $0.6 \mu \mathrm{g} / \mathrm{ml}$, $\mathrm{pH}$ 7.4) with $20,000 \mathrm{cpm}{ }^{125 I}$ [IGF-

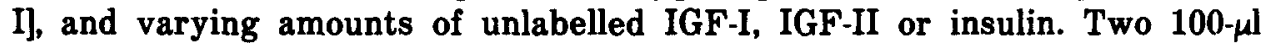
aliquots from each incubation were centrifuged at $100,000 \times g$ for $6 \mathrm{~min}$ in a Beckman Airfuge, and the membrane pellet-associated radiolabel was counted using a LKB Compugamma counter [12].

Specific binding was determined for each individual specimen by subtracting 125I-labelled IGF-I binding that occurred in the presence of excess unlabelled IGF-I from binding in the absence of excess IGF-I. Percent specific binding was calculated using the ratio of specifically bound radiolabel to total radiolabel added. Full competitive binding curves were carried out in those specimens where adequate membrane protein was available, and also in pooled membrane samples from different specimens with similar histology. Human placenta and mouse liver were used as positive and negative controls [13].

\section{RESULTS}

The specific binding of IGF-I to membrane preparations from the individual colon and breast tumours and control tissues is shown in Fig. 1. Note that the positive control tissue, human placenta, is an exceptionally rich source of IGF-I receptors; other IGF-I-responsive tissues exhibit considerably fewer IGF-I binding sites $[13,14]$.

Figure 2A and $B$ show binding displacemnt curves for $\left[{ }^{125}\right.$ I]IGF-I by pooled membrane preparations from 15 colon adenocarcinomas (A) and 6 breast ductal adenocarcinomas (B). Specific binding of IGF-I to the pooled colon and breast membrane preparations were $8.7 \%$ and $7.9 \%$, respectively. Scatchard analysis of binding data in Fig. 2A and 2B, with $K_{d}$-values, are shown in Fig. 3A and B. The colon cancer and breast cancer pooled specimens bound 0.15 and $0.18 \mathrm{pmol}$ IGF-I/mg membrane protein, respectively.

Figures $2 \mathrm{C}$ and $3 \mathrm{C}$ show binding data and Scatchard analysis of IGF-I binding to membranes prepared from a breast tumour classified pathologically as

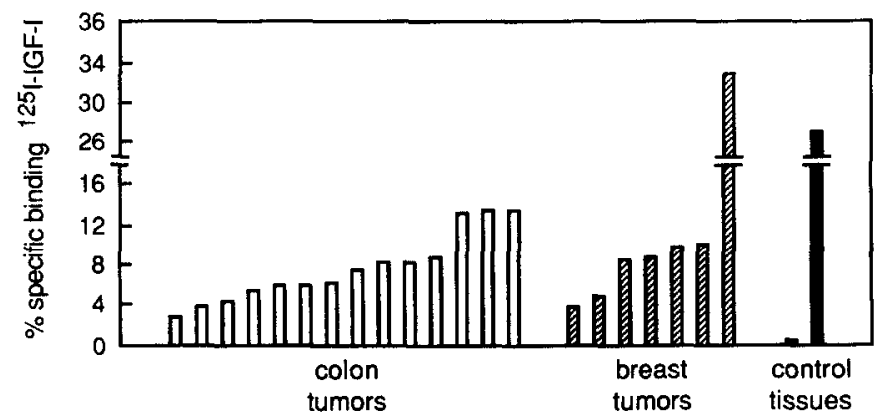

Fig. 1. Specific binding of ${ }^{[28}$ I]IGF-I to individual tumours and control tissues. Assays were performed as described in Materials and Methods. 


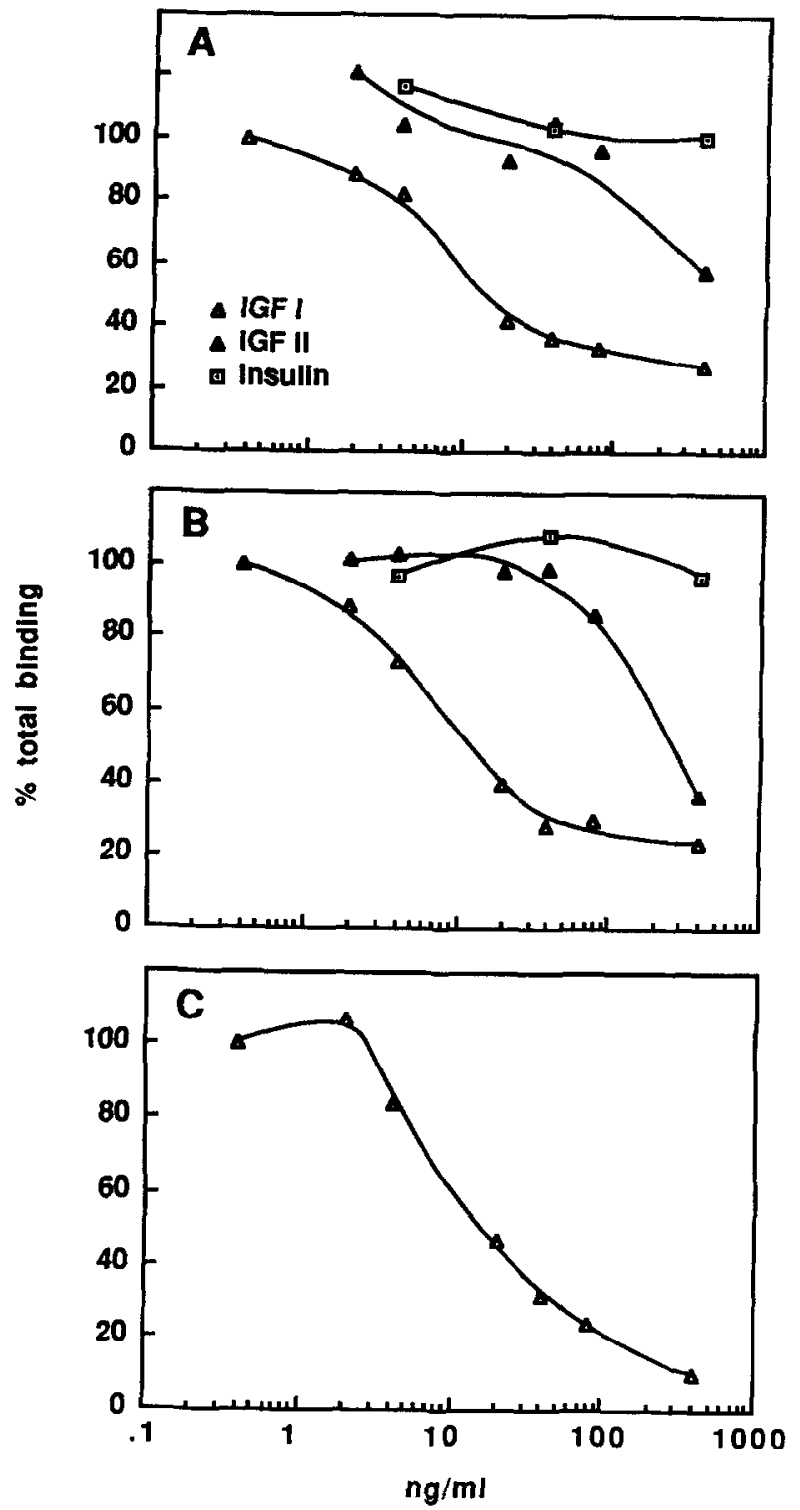

Fig. 2. Competition for binding of ${ }^{225}$-labelled-IGF-I to plasma membrane-enriched subcellular fractions obtained from pooled colon carcinomas (A), pooled breast ductal carcinomas (B), and a lobular breast carcinoma (C) by unlabelled IGF-I, IGF-II and insulin. One hundred percent binding levels represent the amount of labelled IGF-I specifically bound in the absence of competing peptides.

infiltrating lobular carcinoma. This tumour showed $33 \%$ specific binding of IGF-I, and Scatchard analysis was consistent with the presence of significantly more receptors (1.8 $\mathrm{pmol} / \mathrm{mg}$ protein) than the other tumours examined. In general, the number of IGF-I receptors on tumour tissue did not differ 

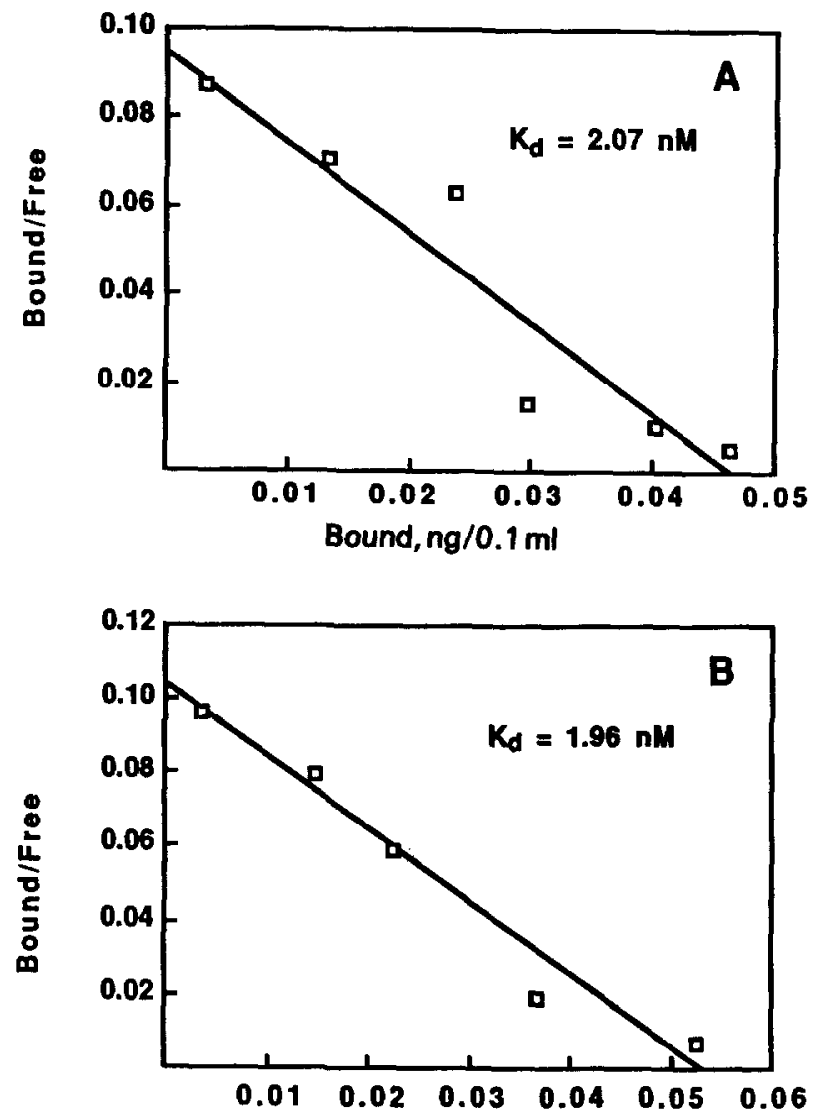

Bound, ng/0.1 ml

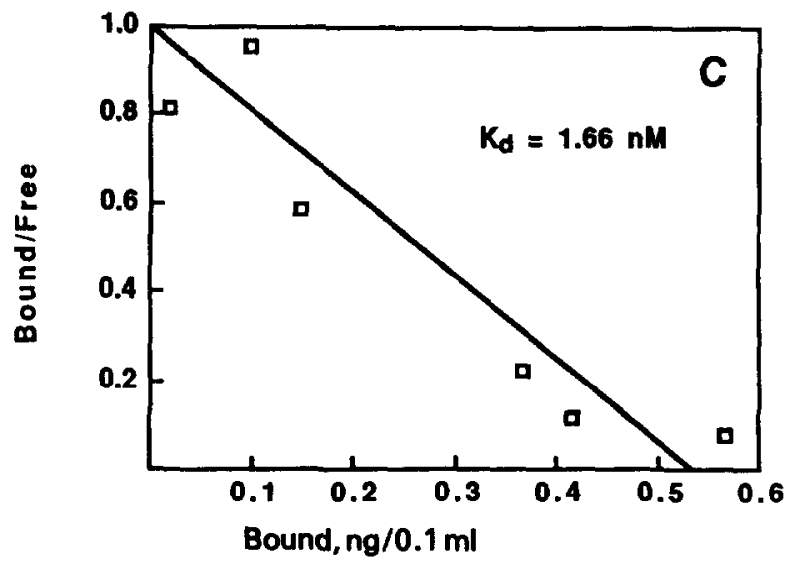

Fig. 3. Scatchard analysis of IGF-I binding data obtained from pooled colon cancers (A), pooled ductal breast cancers (B), and in a single lobular breast cancer selected for further study because of high specific binding of IGF-I (C). 
significantly from levels obtained from adjacent normal tissue (data not shown), but in this case a significant elevation was seen, with specific binding exceeding even that shown by human placenta, a very rich source of IGF-I receptors [13].

\section{DISCUSSION}

In this report, we have demonstrated the presence of IGF-I receptors on primary human breast and colon neoplasms. The IGF-I receptor concentration and binding characteristics appear to be generally similar to those found in tissues whose proliferation is known to be influenced by somatomedins, and to those seen in neoplastic cell lines that have been shown to be growthstimulated in vitro by somatomedins $[15,16]$. These results are consistent with the hypothesis that IGF-I plays a role in determining the proliferative behaviour of primary human breast and colon tumours.

There are at least three mechanisms by which the presence of somatomedin receptors might influence the proliferation of tumours. First, it is possible that IGF-I receptor-positive cancers may exhibit a dependance on exogenous IGF-I for optimum proliferation, in a manner analogous to estrogen dependance of estrogen-receptor-positive breast cancers. Consistent with this possibility is the observation that the in vitro proliferation of certain breast cancer cell lines can be stimulated by somatomedins $[15,16]$. Second, in view of studies demonstrating transcription of the genes encoding somatomedins in colon tumours [17] and in vitro data showing the constitutive production of IGF-I by estrogen-receptor-negative breast cancer cells [18], it is possible that human neoplasms that have somatomedin receptors also themselves produce IGF-I in an unregulated manner. If this is the case, an open 'autocrine' feedback loop involving self-stimulation by somatomedins would exist, and this could lead to neoplastic behaviour [19]. Finally, we have observed an example of a primary neoplasm that exhibits an unusually high number of IGF-I receptors: one may speculate that this tumour is representative of a subset of IGF-I-receptorpositive tumours in which a genetic derangement resulting in elevation of receptor number has occurred. Such an abnormality might contribute to neoplastic growth by rendering cells hypersensitive to 'background' IGF-I concentrations. There is a precedent for this kind of derangement in tumour cell lines exhibiting amplification and overexpression of the gene encoding the epidermal growth factor receptor, an abnormality associated with enhanced in vivo tumour proliferation $[20,21]$.

A survey of a larger number of patients will be necessary to determine if levels of somatomedin receptors on primary tumours and/or concentrations of somatomedins in serum or tissues can be correlated with prognosis or histological grade of human cancers. In view of the ubiquitous distribution of IGF-I receptors in normal tissues, it also will be of interest to determine if these receptors are present on other human neoplasms. Lung, renal and pancreatic cancers will be of particular interest in view of data suggesting a role for 
somatomedins in modulating the proliferation of the tissues of origin of these cancers [22-24].

It is possible that innovative therapeutic approaches could exploit the proposed somatomedin-dependance of IGF-1-receptor-positive human tumours. The use of somatostatin analogues to lower both growth hormone secretion and growth-hormone-dependant somatomedin levels is one approach deserving further study. Although there is some evidence that somatostatin acts directly on certain tumour cells to inhibit proliferation $[25,26]$, it is also possible that some of the activity of this agent seen in animal tumour models [27] is related to suppression of somatomedin levels. The development of competitive antagonists to the IGF-I receptor, and the use of anti-IGF-I-receptor blocking antibodies [28], will be useful in studies concerning the potential therapeutic value of depriving IGF-I-receptor-positive neoplasms of mitogenic stimulation by somatomedins.

\section{ACKNOWLEDGEMENTS}

The assistance of Dr. Louis Begin and members of the Departments of Surgery and Pathology in obtaining specimens is gratefully acknowledged. This study was supported by a grant to M.P. from the Cancer Research Society of Montreal.

\section{REFERENCES}

1 Zapf, J., Schmid, C. and Froesch, E, (1984) Biological and immunological properties of insulinlike growth factors I and II. Clin. Endocrinol. Metab., 13, 3-30.

2 Roberts, C., Brown, A., Graham, D., Seeling, S., Berry, S., Gabbay, K. and Rechler, M. (1986) Growth hormone regulates the abundance of insulin-like growth factor I RNA in adult rat liver. J. Biol. Chem., 261, 10025-10028.

3 Han, V., D'Ercole, J. and Lund, P. (1987) Cellular localization of somatomedin messenger RNA in the human fetus. Science, 236, 193-197.

4 Underwood, L. and D'Ercole, J. (1984) Insulin and insulin-like growth factors/somatomedins in fetal and neonatal development. Clin. Endocrinol. Metab., 13, 69-90.

5 Sasaki, N., Rees-Jones; R., Zick, Y., Nissley, S. and Rechler, M. (1985) Characterization of insulin-like growth factor I stimulated tyrosine kinase activity associated with the beta subunit of type I insulin-like growth factor receptors of rat liver cells. J. Biol. Chem., 260, 9793 -9804 .

6 Ulrich, A., Gray, A., Tam, A., Yang-Feng, T., Tsubokawa, M., Collins, C., Henzel, W., Lebon, T. et al. (1986) Insulin-like growth factor I receptor primary structure: comparison with insulin receptor suggests structural determinants that define functional specificity. EMBO J., 5, 2503 $-2512$.

7 Insulin-like growth factor II binding to the type I somatomedin receptor. Evidence for two high-affinity binding sites. J. Biol. Chem., 261, 9268-9273.

8 Nissley, S. and Rechler, M. (1984) Somatomedin/Insulin-like growth factor tissue receptors. Clin. Endocrinol. Metab., 13, 43-68.

9 Perdue, J., Chan, J., Thibault, C., Radaj, P., Mills, B. and Daughaday, W. (1982) The biochemical characterization of detergent-solubilized insulin-like growth factor II receptors from rat placenta. J. Biol. Chem., 258, 7800 - 7811.

10 Zumstein, P. and Humbel, R. (1985) Purification of insulin-like growth factors I and II. Methods Enzymol. 109, 782-816. 
11 Gowan, L., Hampton, B., Hill, D., Schlueter, R. and Perdue, J. (1987) Purification and characterization of a unique high molecular weight form of IGF-II. Endocrinology, 121, 449458.

$12 \mathrm{Li}, \mathrm{E}$. and Perdue, J. (1980) An airfuge centrifugation procedure for the measurement of ligand binding to membrane-associated and detergent-solubilized plasma membrane receptors. $J$. Biochem. Biophys. Methods, 3, $207-217$.

13 Massague, J. and Czech, M. (1982) The subunit structures of two distinct receptors for insulinlike growth factors I and II and their relationship to the insulin receptor. J. Biol. Chem., $257,5038-5045$.

14 Zapf, J., Schoenle, E. and Froesch, E. (1978) Insulin-like growth factors I and II: some biological actions and receptor binding characteristics of two purified constituents of non-supressible insulin-like activity of human serum. Eur. J. Biochem., 87, 285-296.

15 Furlanetto, R. and Decarlo, J. (1984) Somatomedin-C receptors and growth effects in human breast cells maintained in long-term tissue culture. Cancer Res., 44, 2122-2128.

16 Mayal, Y., Shiu, R., Bhaumick, B. and Bala, M. (1984) Receptor binding and growth-promoting activity of insulin-like growth factors in human breast cancer cells in culture. Cancer Res., 44, $5486-5490$.

17 Tricoli, J., Rall, L., Karakousis, C., Herrera, L., Petrolli, N., Bell, G. and Shows, T. (1986) Enhanced levels of insulin-like growth factor messenger RNA in human colon carcinomas and liposarcomas. Cancer Res., 46, 6169-6173.

18 Huff, K., Kaufman, D., Gabbay, K., Spencer, E., Lippman, M. and Dickson, R. (1986) Secretion of an Insulin-like growth factor-I-related protein by human breast cancer cells. Cancer Res., 46, $4613-4619$.

19 Sporn, M. and Todaro, G. (1980) Autocrine secretion and malignant transformation of cells. N. Engl. J. Med., 303, 878-880.

20 Filmus, J., Trent, J., Pollak, M. and Buick, R. (1987) Epidermal growth factor receptor geneamplified MDA-468 breast cancer cell line and its non-amplified variants. Mol. Cell. Biol., 7, 251 $-257$.

21 Santon, J., Cronin, M., MacLeod, C., Mendelsohn, J., Masui, H. and Gill, G. (1986) Effects of epidermal growth factor receptor concentration on tumorigenicity of A431 cells in nude mice. Cancer Res., 46, 4701 - 4705.

22 Bhaumick, B. and Bala, R. (1987) Binding and degradation of insulin-like growth factors I and II by rat kidney membrane. Endocrinology, 120, 1439-1448.

23 Weidman, E. and Bala, R. (1980) Direct mitogenic effects of human somatomedin in human embryonic lung fibroblasts. Biochem. Biophys. Res. Commun., 92, 577-585.

24 Williams, J., Bailey, A., Humbel, R. and Goldfine, J. (1984) Insulin-like growth factors bind to specific receptors in isolated pancreatic acini. Am. J. Physiol., 246, G96-G99.

25 Hierowski, M., Liebow, C., Sapin, K. and Schally, A. (1985) Stimulation by somatostatin of dephosphorylation of membrane proteins in pancreatic cancer MIA-Pa-Ca-2 cell line. FEBS Lett., 79, 252-256.

26 Setyono-Han, B., Henkelman, M., Foekens, J. and Klijn, J. (1987) Direct inhibitory effects of somatostatin on the growth of human breast cancer cells. Cancer Res., 47, 1566-1570.

27 Paz-Bouza, J., Redding, T. and Schally, A. (1987) Treatment of nitrosamine-induced pancreatic tumors in hamsters with analogs of somatostatin and luteinizing hormone-releasing hormone. Proc. Natl. Acad. Sci. U.S.A., 84, 1112-1116.

28 Flier, J., Usher, P. and Moses, A. (1986) Monoclonal antibody to the type I insulin-like growth factor receptor blocks IGF-I receptor-mediated DNA synthesis: clarification of the mitogenic mechanisms of IGF-I and insulin in human skin fibroblasts. Proc. Natl. Acad Sci. U.S.A., 83, 664 -668 . 